\title{
Effects of heating rate and heating up time to central biomass particles for bio-oil production
}

\author{
M. B. Ahmed, A.T. M. K. Hasan, M. Mohiuddin, M. Asadullah, M. S. Rahman and A. Khaleque \\ Chemical Engineering Research Laboratory, Department of Applied Chemistry and Chemical Engineering, \\ University of Rajshahi, Rajshahi-6205, Bangladesh
}

\begin{abstract}
Objective of this work was to pyrolysis woody biomass. Experiments were carried out at 300 to $500{ }^{\circ} \mathrm{C}$. Relatively bigger particles were used. Special emphasis was given to investigate the effects of heating rate and heating up time of the central mass of the particles on the product distribution. Surface temperature reached to the reactor set temperature immediately while the temperature at the central part was as low as $50{ }^{\circ} \mathrm{C}$. The center temperature gradually increased to the final temperature within 3 to 8 minutes, depending on the wood types and the reactor set temperature. For ipil-ipil wood the heating rate of the central mass was much faster than krishnachura and koroi woods, and thus the heating up time was lower. Ipil-ipil wood was experienced higher yield $(65 \%)$ even at lower reactor temperature $300{ }^{\circ} \mathrm{C}$ with particle temperature $450{ }^{\circ} \mathrm{C}$. In the case of krishnachura and koroi woods, the bio-oil yields were lower under the same condition due to the heating rates of the central parts were much slower. Further researchon different biomasses may be necessary to demonstrate overall process.
\end{abstract}

Keywords: Woody biomass; Bio-oil; Pyrolysis; Reactor; Fossil fuels

\section{Introduction}

Energy is an integral part of a society and plays a pivotal role in its socio-economic development by raising the standard of living and the quality of life. The state of economic development of any region can be assessed from the pattern and consumption quality of its energy uses. Energy demand increases as the economy grows bringing along a change in the consumption pattern, which in turn varies with the source and availability of its energy, conversion loss and end use efficiency (Dodić et al., 2010; Kanakraj et al., 2014). Through the different stages of development, humankind has experimented with various sources of energy ranging from wood, coal, oil and petroleum to nuclear power (Demirbas, 2004; McKendry, 2002). Industrializations during the nineteenth century witnessed dependence on resources such as coal, oil, and gas (Grubler, 2012).

Fossil fuel such as natural gas, petroleum and coal is the major source of energy now-a-days. Projections from the World Energy Council and others (Banik et al., 2015; Ghose, 2013) are that oil and gas should both be available through most of this century, and that the present coal production could be for more than 200 years (Bentley, 2002; Moriarty and Honnery, 2009). This limitation of fossil fuel sources is threatening to the energy depended future generation in one hand and the use of these huge amount of fuels within this short span of time is causing abnormal increase of $\mathrm{CO}_{2}$ on the other hand that ultimately making the atmosphere unsuitable for human being (Awal, 2010; Song et al., 2002). Therefore, many efforts and counter measurements have been attempted to reduce the emission of greenhouse gases, especially $\mathrm{CO}_{2}$, such as fuel switching although it may involve a structural change in the energy supply system, developing the technologies of improved efficiency of carbon fuels (Rao and Rubin, 2002; Yousuf et al., 2014).

For the development of new technologies on the renewable and sustainable energy, for example solar, wind and/or tide energy has still many problems in the technology. These renewable energy sources are quite friendly to the environment (Asif and Muneer, 2007; Dincer, 2000). However, the limited area of application, low production efficiency, high production cost and many other technological problems slow down the development of this energy field and will take prolong time to commercialize or even impossible to commercialize in developing countries (McNeil's et al., 2002).

*Corresponding author. e-mail: boshiracct576@yahoo.com 
Biomass, a potentially $\mathrm{CO}_{2}$-neutral, isabundantly produced in the forest and in agricultural field everywhere in the world and thus readily accessible (Sakaki and Yamada, 1997; Kaygusuz, 2002). In terms of the cost, it is a least cost energy source and sometimes it has negative cost associated with its disposal in the rural area especially in the developing countries (McGowan, 1991; Kinoshita et al.,1997). Thus the energy such as electricity and heat generation from biomass are considered the most lucrative opportunity for commercial exploitation and environmental protection, since the high value of electricity and heat (Van den Broek et al., 2000; Saleh et al., 2010).

The power generation efficiency from the biomass fuel is the most important factor for achieving the potential utilization of biomass (Imran et al., 2012; Rana et al., 2015). Advanced conversion technologies such as pyrolysis (Ganesh and Banerjee, 2001) and gasification (Asadullah, 2014) can offer methods of power generation with higher efficiencies than combustion based steam cycles. In these processes biomass is first converted to liquid called bio-oil which is a mixture of about 200 types of organic compounds (Hasan et al., 2011; Hasan et al., 2010) (fast pyrolysis) or gaseous (gasification) fuels, which are then burned in the engines or gas turbines. The heat generated by this process is converted to power at a higher temperature than in the simple steam cycle giving the potential for thermodynamically more efficient process (Asadullah et al., 2004).

Different biomass conversion processes have different residence time and temperature of pyrolysis. These depend on the particle size and conversion temperature (Demirbas, 2004; Sharma et al., 1998). Smaller the particle higher the conversion efficiency but it has high cost to make it small particles. And thus for large scale production it is necessary to consider about cost and also the size of the particles.

Thus in this study the production of liquid fuel was considered by pyrolysis of biomass. Biomass in various forms is available in Bangladesh, however, woody biomass as a model for biomass was considered for bio-oil production by pyrolysis. In this study, the main aims were to (i) study the effects of heating rate and heating up time of the central mass of the particles on the product distribution, (ii) calculate the yield of bio-oil for different biomasses and (iii) comparative product distribution analysis of the different biomasses pyrolysis.

\section{Materials and methods}

\section{Feedstock's preparation}

The feedstock's considered in this study were three different types of woods such as ipil-ipil wood, krishnachura wood and koroi wood, which are cheap raw materials (Nessa et al., 2014) and abundantly available in Bangladesh.The raw materials (ipil-ipil, krishnachura and koroi wood particles) usually contain moisture more than 10 wt. \% which usually causes difficulty to feed into the pyrolysis reactor. In addition, the high moisture content in the raw materials results in high water content in the bio-oil. To ensure the consistent feeding and optimized pyrolysis products, the feedstock's were dried to below $10 \mathrm{wt} . \%$ moisture content and particles made to about 3-4 $\mathrm{cm}$ length and $2-3 \mathrm{~cm}$ wide in size. The properties as well as ultimate and proximate analyses of the biomass were carried out and summarized in Table I and II..

\section{Table I. Proximate analysis and other characteristics} data (average value)

\begin{tabular}{lc}
\hline Proximate analysis & Experimental value \\
\hline Volatile fraction (wt. \%) & $76-78$ \\
Fixed carbon (wt. \%) & $21.4-23.4$ \\
Ash content (wt. \%) & $0.60-0.75$ \\
Other characteristics & --- \\
Moisture content (wt. \%) & $3-12$ \\
Particle size in diameter (cm) & $2-3$ \\
Particle size in length (cm) & $3-4$ \\
Density for krisnachura tree $(\mathrm{g} / \mathrm{cc})$ & 0.27 \\
Heating value (HHV) $(\mathrm{MJ} / \mathrm{kg})$ & $17-19$ \\
\hline
\end{tabular}

Table II. Ultimate analysis of typical biomass (dry basis)

\begin{tabular}{lccccc}
\hline Name & $\% \mathrm{C}$ & $\% \mathrm{H}$ & $\% \mathrm{O}$ & $\% \mathrm{~N}$ & $\% \mathrm{~S}$ \\
\hline Ipil-ipil & 48.30 & 6.80 & 42.50 & & \\
Krisnachura & 48.09 & 7.68 & $43.68\left(\right.$ withN $\left._{2}\right)$ & & 0.55 \\
Koroi & 48.13 & 5.87 & 42.46 & 1.45 & 0.00 \\
\hline
\end{tabular}




\section{Characterization of woody biomass}

The woody biomass was first characterized by measuring the particle size, density, moisture content, $\mathrm{pH}$ determining, heating value and by ultimate and proximate analyses. The ultimate analysis and proximate analysis of the woody biomass was carried out by many researchers as shown in Table II (Kibria, 1994; Mwang'ingo, 2010; Suarez, 2000; Vargasa et al., 2011).

\section{Pyrolysis of woody biomasses}

About 3-4 $\mathrm{cm}$ long biomass particles were fed batch wise into the reactor to measure the product distribution and heating rate of the central part of the biomass as the experimental setup shown in Fig. 1. The biomass particles were drilled with a $1 \mathrm{~mm}$ diameter drill beet. Then a $1 \mathrm{~mm}$ diameter ther-

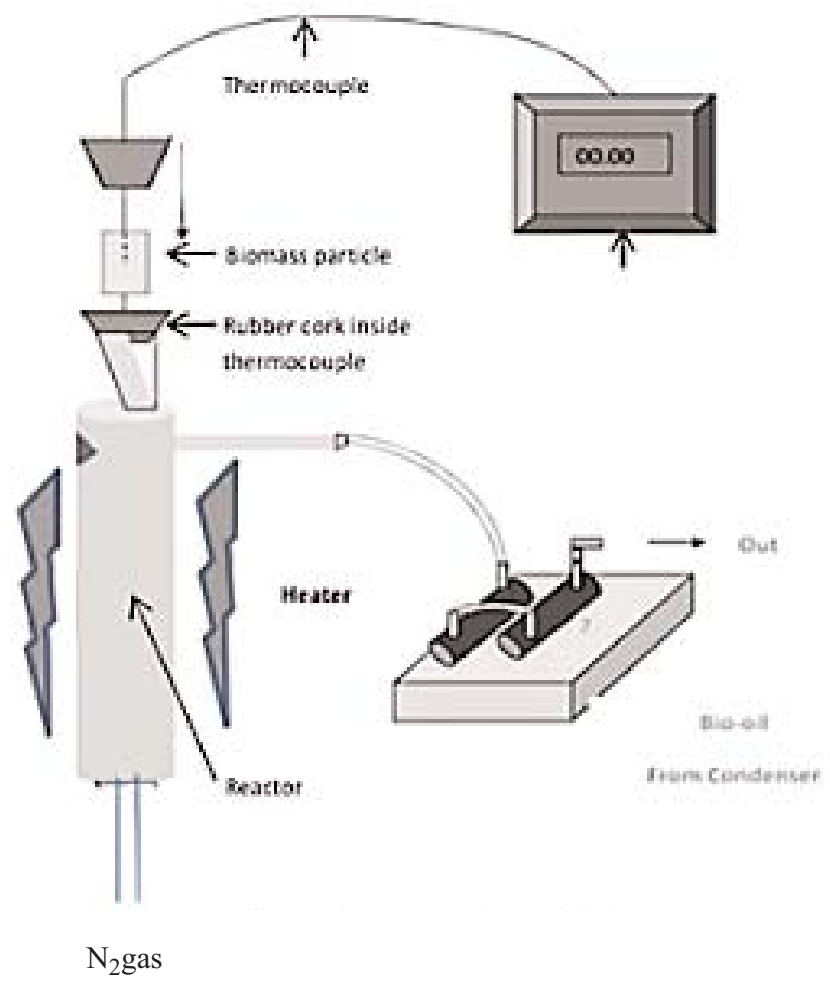

Fig. 1. Design of pyrolysis reactor

mocouple was inserted through the hole. The thermocouple tip was kept at the center of the particle. Before inserting the thermocouple into the biomass particle, it was inserted through a heat proof rubber cork. When the biomass particle was fed along with the thermocouple just at the center of the reactor, the heat proof rubber cork was blocked the reactor inlet as it was adjusted exactly the same distance before heating up the reactor. The reactor is made of mild steel with a height of $42 \mathrm{~cm}$ and a diameter of $4.5 \mathrm{~cm}$. In both of the experiments, the biomass particles were heated with heater. The reactor was heated to the desired temperature before starting the feeding of biomass. Nitrogen gas flow of 450 $\mathrm{mL} / \mathrm{min}$ was usually used for avoiding any combustion reactions in the reactor during the feeding of biomass. The flow of nitrogen replaces the air from the reactor and permits the pyrolysis reaction under anaerobic condition. The vapor produced in the reactor was passed through a series of ice cooled condenser where it was condensed as bio-oil. To avoid any loss of liquid collection in order to accurately measure the liquid yield, the condenser was weighed before and after the condensation of bio-oil vapor. The weight of bio-oil was accounted from the difference of the weights. The char was collected after cooling down the reactor and weighed. The yield of gas was measured from the difference of the weights of biomass fed and the total weight of liquid and solid char. The temperature of the reactor was displayed by temperature monitors through thermocouple. The process was carried out under atmospheric pressure

\section{Bio-oil characterization}

Bio-oil is usually a dark brown viscous liquid. It was characterized by measuring the $\mathrm{pH}$, density, water content, solid content, pyro lytic lignin content, acid value etc. The density was measured with a density measurement bottle. Viscosity of the bio-oil is the measure of its internal friction which resists the flow of the fluid. Water content in the biooil was measured by Karl-Fischer titrimetric method. The $\mathrm{pH}$ was measured with a digital $\mathrm{pH}$ meter (Hanna Model-HI 8424). The solid content in the pyrolysis oil was measured as ethanol insoluble portion. The lignin portion was measured as water insoluble fraction by using phase separation. The acid value of the bio-oil was determined by direct titration with standard potassium hydroxide solution. Ash content was calculated by burning the bio-oil with supplying excess air in a muffle furnace. 


\section{Results and discussion}

Biomass is abundantly available in Bangladesh in different forms such as agricultural residues, forestry bi-products, industrial wastes and municipal wastes. The sources of biomasses for this study are cultivated at different places in Bangladesh which includes ipil-ipil tree, koroi tree and krishnachura tree. The local name and scientific nameof these trees are listed in Table III (Kibria, 1994; Mwang'ingo, 2010; Suarez, 2000; Vargasa et al., 2011). Characteristics data of those woody biomasses are given in the Tables I-II.

Table III. Local name, scientific name and heating value of the experimental woods

\begin{tabular}{llc}
\hline Local name & Scientific name & $\begin{array}{c}\text { Experimental } \\
\text { HHV }(\mathrm{MJ} / \mathrm{Kg})\end{array}$ \\
\hline Ipil-ipil & Leucaena leucocephala & 20.22 \\
Krisnachura & Delonix regia & $17-19$ \\
Koroi & Albizia spp & $17-19$ \\
\hline
\end{tabular}

\section{Pyrolysis of woody biomasses}

Here the pyrolysis of woody biomasses was performed in a reactor as designed in a laboratory scale reactor. The woody biomass of the size 2-3 cm diameter and 3-4 cm length including thermocouple was fed into the reactor. The nitrogen gas was passed through the bottom of the reactor. The furnace temperature was controlled by a temperature controller. The reactor was heated to a desired temperature before feeding biomass. After inserting the piece of biomass with thermocouple, the particle heating rate was counted on temperature controller screen. The data was recorded roughly every after two second. The surface of the biomass was immediately exposed to the set temperature while the tem- perature at the center was gradually increased. The pyrolysis vapors were condensed and collected by two condensers prepared locally. Two condensers were set in an ice cold bath where the inlet of the vapors was connected to the one end and the outlet of the non-condensable gases was connected to the other end which was set at the ventilation of the laboratory. The non-condensable gas is exposed into the air.

Effect of reactor temperature on bio-oil yield from three different woods

Table IV represents the effect of temperature on the bio-oil yield from ipil-ipil wood. The yield of bio-oil is the maximum at $300{ }^{\circ} \mathrm{C}$ reactor set temperature and it decreased with increasing temperature. The duration of complete pyrolysis of total mass was also decreased with increasing temperature. When biomass was fed even at $300{ }^{\circ} \mathrm{C}$, the pyrolysis was started and substantial amount of bio-oil was produced as shown in Table IV. The pyrolysis started from the surface and gradually moved towards the center of the particle. Therefore, the complete pyrolysis of the particle depends on three factors: 1 . the particle diameter, 2. temperature gradient, and 3. thermal conductivity of the particle. After feeding, the surface component immediately got the reactor temperature and suddenly decomposed to the volatile matter. If the particle size is small enough ( $\mathrm{mm}$ range), the location of the pyrolysis temperature zone in the particle would immediately arrive in the center part and take less time to be completely pyrolyzed. However, we have used comparatively very big size of the particle (3-4 cm length and 2-3 cm diameter) where a far distance for pyrolysis temperature zone in the particle to travel. Furthermore, since the woody materials are less thermal conductive, the heat transfer rate to the center part is substantially low. This gives rise to the slow heating of the center mass and takes longer time to be completely pyrolyzed as is shown in Table IV.

Table IV. Yield of bio-oil from ipil-ipil woody biomass pyrolysis at different temperatures

\begin{tabular}{lccccccc}
\hline $\begin{array}{c}\text { Exp. } \\
\text { No. }\end{array}$ & $\begin{array}{c}\text { Wt. of particle } \\
\text { gm. }\end{array}$ & $\begin{array}{c}\text { L of particle } \\
\text { cm }\end{array}$ & $\begin{array}{c}\text { D of particle } \\
\text { cm }\end{array}$ & $\begin{array}{c}\text { Ractor } \\
\text { temp. }{ }^{\circ} \mathrm{C}\end{array}$ & $\begin{array}{c}\text { Volatile } \\
\text { release min }\end{array}$ & $\begin{array}{c}\text { Amount of } \\
\text { oil g }\end{array}$ & $\begin{array}{c}\text { Yield of } \\
\text { oil\% }\end{array}$ \\
\hline 1 & 7.68 & 4.00 & 2.55 & 300 & 8.24 & 5.0 & 65.0 \\
2 & 7.87 & 4.00 & 2.55 & 350 & 7.26 & 4.7 & 59.6 \\
3 & 7.96 & 4.00 & 2.65 & 400 & 5.58 & 3.7 & 46.4 \\
4 & 7.57 & 3.90 & 2.55 & 450 & 4.20 & 3.4 & 44.8 \\
5 & 6.95 & 4.00 & 2.35 & 500 & 3.41 & 2.7 & 36.5 \\
\hline
\end{tabular}


Heat transfer rate also depends on the temperature gradient, the higher the gradient the higher the heat transfer rate. The higher set temperature to the reactor resulted in higher gradient of temperature from the surface to the center which inevitably promoted the heat flow rate and decreased the total duration of complete pyrolysis of total mass. It is to mention that the primary pyrolysis at just the decomposition temperature is endothermic; however, the secondary pyrolysis at higher temperatures than decomposition temperature is exothermic. In the case of bigger particles of biomass, the heat generated by exothermic reaction was completely added to the inward transferred heat, so as to increase the actual temperature of the central part of the particle. It seems that the final pyrolysis proceeded at the central part was at higher temperature than that of the reactor set temperature. The higher temperature facilitates more preferably to form gas, and thus the bio-oil yield at higher temperature is lower (Table IV). On the other hand, the lower temperature facilities more preferably to form solid char. At lower temperature, when cellulosic compounds decompose the re-polymerization and cross linking reactions are predominantly preceded which led to the formation of solid char.
Table V and VI represent the effect of temperature on the bio-oil yields from krisnachura and koroi wood biomasses, respectively. The pyrolysis rate also depends on the characteristics of wood. The soft wood is usually decomposed faster than that of the hard wood. The krisnachura wood is much harder than ipil-ipil wood and the koroi is the hardest one among them as from carpenter's experience. Therefore, the pyrolysis rate of ipil-ipil wood would be much faster than others and it was reflected in the highest bio-oil yield at the lowest temperature $\left(300^{\circ} \mathrm{C}\right)$ for ipil-ipil wood. The maximum yield of bio-oil $(66 \%)$ was achieved at $400^{\circ} \mathrm{C}$ for krisnachura wood. The pyrolysis of the hardest wood (koroi) was very slow and the bio-oil yield was very low and it was less than $50 \%$ in all temperatures.

Effect of heating up rate of central mass on the product distribution

Tables VII, VIII and IX exhibit the yield of solid, liquid and gas as a function of heating rate of the central part of the biomass particles. Fig. 2 to Fig. 7 show the relationship of heat ing up time and final temperature at the central mass with the

Table V. Yield of bio-oil from krisnachura biomass pyrolysis at different temperatures

\begin{tabular}{lccccccc}
\hline $\begin{array}{c}\text { Exp. } \\
\text { No. }\end{array}$ & $\begin{array}{c}\text { Wt. of particle } \\
\text { gm. }\end{array}$ & $\begin{array}{c}\text { L of particle } \\
\mathrm{cm}\end{array}$ & $\begin{array}{c}\text { D of particle } \\
\mathrm{cm}\end{array}$ & $\begin{array}{c}\text { Ractor } \\
\text { temp. }{ }^{\circ} \mathrm{C}\end{array}$ & $\begin{array}{c}\text { Volatile } \\
\text { release min }\end{array}$ & $\begin{array}{c}\text { Amount of } \\
\text { oil g }\end{array}$ & $\begin{array}{c}\text { Yield of } \\
\text { oil\% }\end{array}$ \\
\hline 1 & 11.41 & 3.95 & 2.60 & 300 & 7.45 & 7.0 & 61.2 \\
2 & 11.00 & 3.90 & 2.35 & 350 & 7.20 & 5.9 & 53.6 \\
3 & 11.98 & 4.00 & 2.70 & 400 & 6.42 & 8.0 & 66.7 \\
4 & 11.80 & 4.00 & 2.65 & 450 & 6.10 & 4.9 & 41.4 \\
5 & 12.75 & 4.10 & 2.75 & 500 & 5.35 & 5.0 & 39.1 \\
\hline
\end{tabular}

Table VI. Yield of bio-oil from koroi wood biomass pyrolysis at different temperatures

\begin{tabular}{lccccccc}
\hline $\begin{array}{c}\text { Exp. } \\
\text { No. }\end{array}$ & $\begin{array}{c}\text { Wt. of particle } \\
\text { gm. }\end{array}$ & $\begin{array}{c}\text { L of particle } \\
\mathrm{cm}\end{array}$ & $\begin{array}{c}\text { D of particle } \\
\mathrm{cm}\end{array}$ & $\begin{array}{c}\text { Reactor temp. } \\
{ }^{\circ} \mathrm{C}\end{array}$ & $\begin{array}{c}\text { Volatile } \\
\text { release min }\end{array}$ & $\begin{array}{c}\text { Amount of } \\
\text { oil g }\end{array}$ & $\begin{array}{c}\text { Yield of } \\
\text { oil\% }\end{array}$ \\
\hline 1 & 10.27 & 4.00 & 2.60 & 300 & 7.59 & 4.9 & 47.6 \\
2 & 10.31 & 3.90 & 2.70 & 350 & 7.25 & 5.2 & 50.3 \\
3 & 9.47 & 4.00 & 2.70 & 400 & 5.37 & 4.6 & 49.0 \\
4 & 10.72 & 4.00 & 2.75 & 450 & 5.58 & 5.2 & 48.4 \\
5 & 9.36 & 4.00 & 2.50 & 500 & 4.52 & 3.6 & 42.3 \\
\hline
\end{tabular}


Table VII. Effect of heating rate of the central mass of the ipil-ipil wood particle on the product distribution

\begin{tabular}{|c|c|c|c|c|c|c|c|}
\hline $\begin{array}{c}\text { Wt. of } \\
\text { Particle } \\
\text { gm. }\end{array}$ & $\begin{array}{l}\text { Reactor temp. } \\
{ }^{\circ} \mathrm{C}\end{array}$ & $\begin{array}{c}\text { Central temp. } \\
{ }^{\circ} \mathrm{C}\end{array}$ & $\begin{array}{l}\text { Central heat- } \\
\text { ing up time } \\
\text { min }\end{array}$ & $\begin{array}{l}\text { Heating rate of } \\
\text { central mass } \\
{ }^{\circ} \mathrm{C} / \mathrm{min}\end{array}$ & $\begin{array}{c}\text { Yield of oil } \\
\%\end{array}$ & $\begin{array}{c}\text { Yield of char } \\
\%\end{array}$ & $\begin{array}{c}\text { Yield of gas } \\
\%\end{array}$ \\
\hline 7.68 & 300 & 425 & 8.24 & 48.54 & 65.0 & 26.03 & 08.89 \\
\hline 7.87 & 350 & 485 & 7.26 & 63.36 & 59.6 & 24.13 & 16.18 \\
\hline 7.96 & 400 & 545 & 5.58 & 93.18 & 46.4 & 16.31 & 37.26 \\
\hline 7.57 & 450 & 600 & 4.20 & 136.90 & 44.8 & 15.83 & 39.30 \\
\hline 6.95 & 500 & 625 & 3.41 & 175.95 & 36.5 & 14.38 & 49.08 \\
\hline
\end{tabular}

Table VIII. Effect of heating rate of the central mass of the krisnachura wood particle on the product distribution

\begin{tabular}{|c|c|c|c|c|c|c|c|}
\hline $\begin{array}{l}\text { Wt. of } \\
\text { Particle } \\
\text { gm. }\end{array}$ & $\begin{array}{l}\text { Reactor temp. } \\
{ }^{\circ} \mathrm{C}\end{array}$ & $\begin{array}{l}\text { Central temp. } \\
{ }^{\circ} \mathrm{C}\end{array}$ & $\begin{array}{l}\text { Central heat- } \\
\text { ing up time } \\
\text { min }\end{array}$ & $\begin{array}{l}\text { Heating rate of } \\
\text { central mass } \\
{ }^{\circ} \mathrm{C} / \mathrm{min}\end{array}$ & $\begin{array}{c}\text { Yield of oil } \\
\%\end{array}$ & $\begin{array}{c}\text { Yield of char } \\
\%\end{array}$ & $\begin{array}{c}\text { Yield of gas } \\
\%\end{array}$ \\
\hline 11.41 & 300 & 415 & 7.45 & 55.70 & 61.20 & 30.29 & 08.42 \\
\hline 11.00 & 350 & 475 & 7.20 & 65.97 & 53.60 & 29.08 & 17.30 \\
\hline 11.98 & 400 & 530 & 6.42 & 82.55 & 66.70 & 25.03 & 08.21 \\
\hline 11.80 & 450 & 590 & 6.10 & 96.72 & 41.40 & 22.86 & 35.65 \\
\hline 12.75 & 500 & 620 & 5.35 & 115.88 & 39.10 & 18.02 & 42.80 \\
\hline
\end{tabular}

Table IX. Effect of heating rate of the central mass of the koroi wood particle on the product distribution

\begin{tabular}{cccccccc}
\hline $\begin{array}{c}\text { Wt. of } \\
\text { Particle } \\
\text { gm. }\end{array}$ & $\begin{array}{c}\text { Reactor temp. Central temp. } \\
{ }^{\circ} \mathrm{C}\end{array}$ & $\begin{array}{c}\text { Central heat- } \\
\text { ing up time } \\
\text { min }\end{array}$ & $\begin{array}{c}\text { Heating rate of } \\
\text { central mass } \\
{ }^{\circ} \mathrm{C} / \mathrm{min}\end{array}$ & $\begin{array}{c}\text { Yield of oil } \\
\%\end{array}$ & $\begin{array}{c}\text { Yield of char } \\
\%\end{array}$ & $\begin{array}{c}\text { Yield of gas } \\
\%\end{array}$ \\
\hline 7.68 & 300 & 420 & 7.59 & 55.35 & 47.69 & 23.36 & 28.95 \\
7.87 & 350 & 480 & 7.25 & 66.20 & 50.39 & 23.25 & 26.36 \\
7.96 & 400 & 535 & 5.37 & 99.62 & 49.05 & 23.22 & 27.73 \\
7.57 & 450 & 595 & 5.58 & 106.63 & 48.47 & 18.64 & 32.89 \\
6.95 & 500 & 625 & 4.52 & 138.27 & 38.43 & 19.21 & 42.36 \\
\hline
\end{tabular}

reactor set temperature. For the ipil-ipil wood (Table VII), the heating rate of the central mass varied from $48^{\circ} \mathrm{C} / \mathrm{min}$ to $176^{\circ} \mathrm{C} / \mathrm{min}$ depending on the reactor set temperatures. With the higher heating rate at the center part of the biomass, biooil and solid char yields are decreased while the gas yield increased. Higher the reactor set temperature, higher is the temperature difference, which leads to the faster heat transfer rate from the surface to the center. Faster heating of cellulosic biomass predominantly leads to the gas formation rather than the formation of organic molecules which ultimately goes to the bio-oil. This is the main reason of higher gas yield and lower bio-oil yield at higher temperature. Furthermore, the faster heating rate prevents the polymeriza-

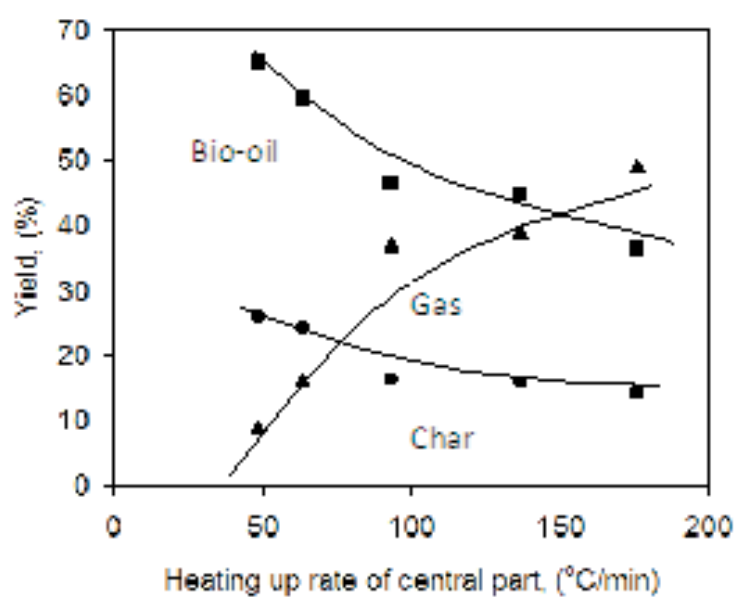

Fig. 2. Relationship between heating up rate of centralpart and yields of solid, liquid and gas from ipilipil wood. 
tion and cross linking reactions among the organic molecules produced from the decomposition of biomass. This supports the decreasing trends of solid char yields with increasing heating rate.

The heating rate of the central mass of krisnachura and koroi wood is significantly different from that of the ipil-ipil wood. Although the reason is not clear it may be due to the compo-

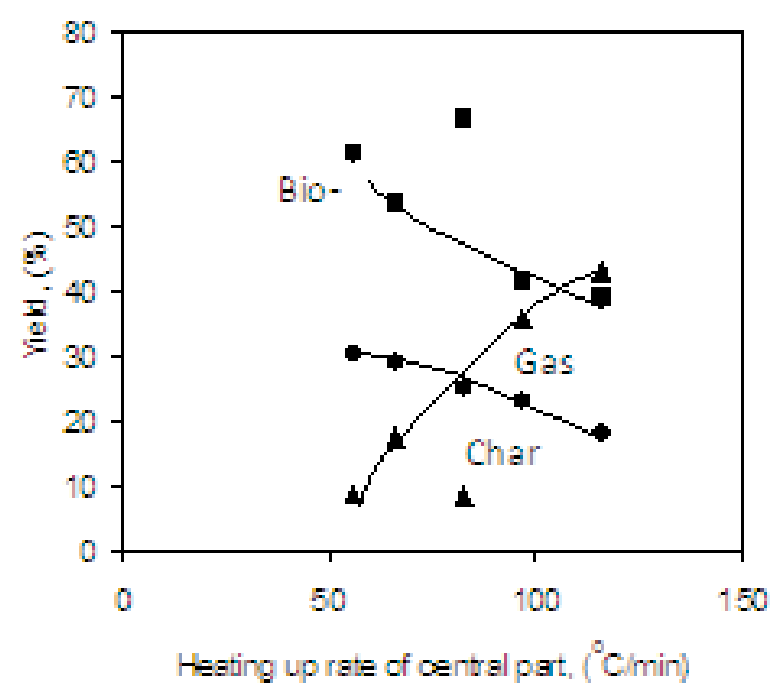

Fig. 3. Relationship between heating up rate of central part and yields of solid, liquid and gas from krishnachura wood.

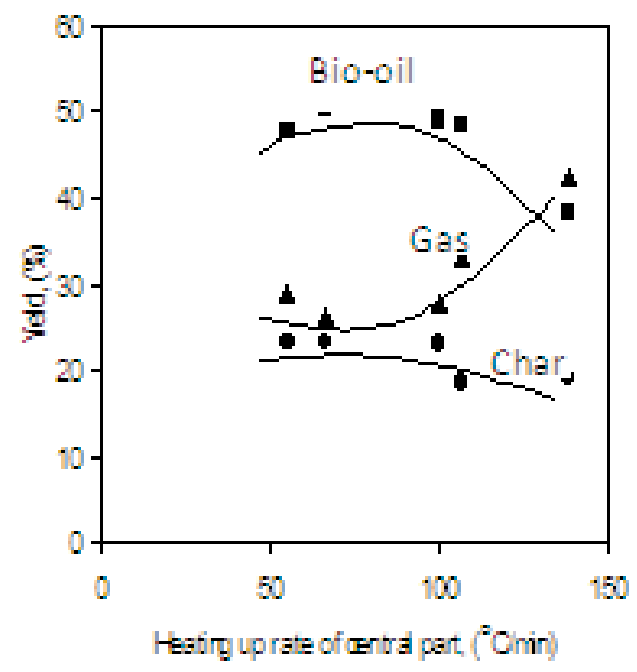

Fig. 4. Relationship between heating up rate of central part and yields of solid, liquid and gas from koroi wood. sitional difference of the woods. The heating rate of the ipilipil wood is much faster than other two at the higher temperature levels. We have also obtained the higher yield of biooil for ipil-ipil wood. These results indicate that the ipil-ipil wood underwent in much faster pyrolysis. Furthermore, it is evident that the pyrolysis of woody biomass at above decomposition temperature $\left(300-400^{\circ} \mathrm{C}\right)$ is exothermic. Therefore, the heat released from the pyrolysis reaction along with the heat transferred from the surface heated up the central mass much faster than other two. Due to the faster heating rate, the gas yield is higher for ipil-ipil wood at the higher temperature range. In the case of krisnachura and koroi woods, the pyrolysis rate is slow, and thus the exothermic heat releasing rate is also slow which resulted in overall slow heating rate at the central mass. This slow heating rate reflected to the higher char yield and lower gas yields for this two woods. Figs. 2 to 4 show the relationship between the heating rate and the product distribution. Fig. 2 clearly indicates the faster decrease of the yields of liquid and solid while the faster increase of the gas yield from ipil-ipil wood. However, as shown in Fig. 4, the decreasing trend of liquid and solid is comparatively very slow from koroi wood. In other word, the increasing trend of gas yield is slow from this wood. Figs. 5 to 7 represent the final temperature of the central mass and the duration of the volatile release as a function of the reactor temperature. When the particle was thrown

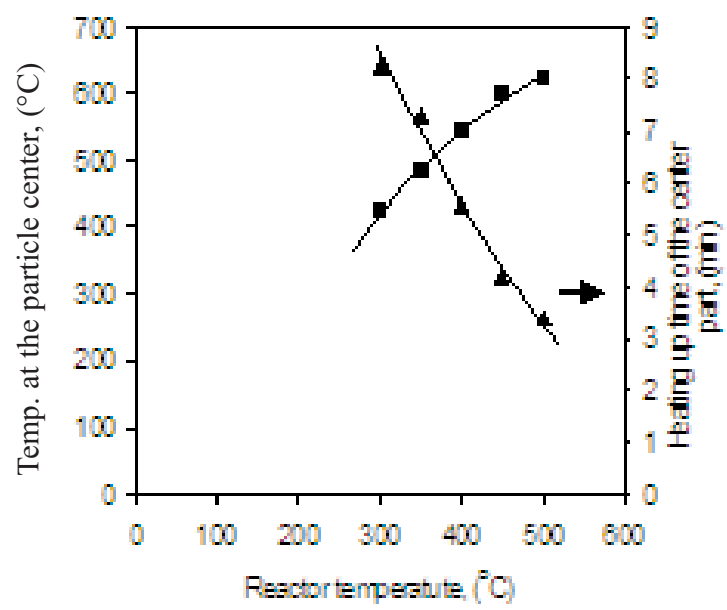

Fig. 5. Resulted final temperature and the duration of volatile release as a function of reactor temperature for ipil-ipil wood. 
into the reactor along with the thermocouple embedded inside the biomass particle (3-4 $\mathrm{cm}$ long with $2-3 \mathrm{~cm}$ diameter), the center temperature just started to increase while the surface temperature reached to the reactor temperature. The center temperature gradually increased and the pyrolysis started when it reached to $250-260^{\circ} \mathrm{C}$. Initially, the pyrolysis reaction was endothermic; however it turned to the

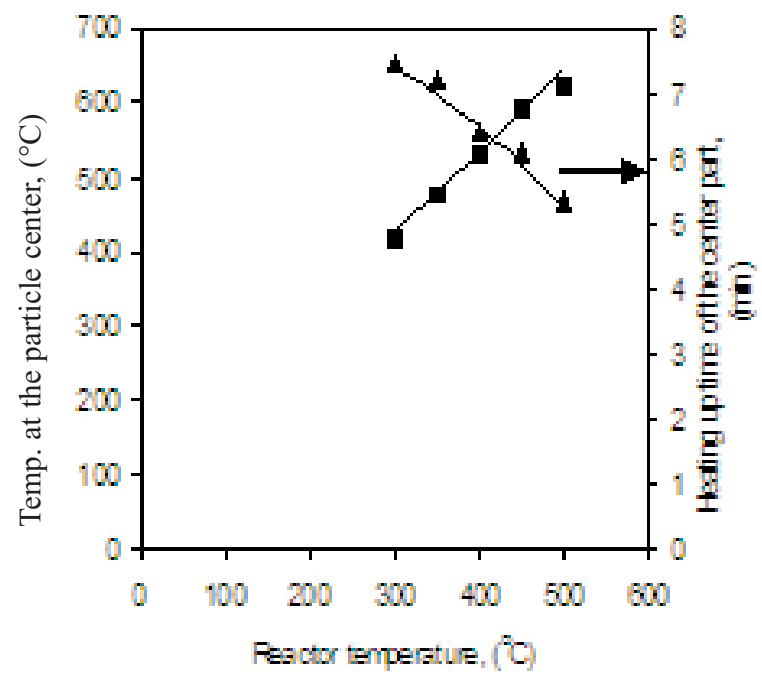

Fig. 6. Resulted final temperature and the duration of volatile release as a function of reactor temperature for krisnachura wood.

exothermic when it reached at around $400^{\circ} \mathrm{C}$ and immediately reached to the final temperature. This is because the heat transferred from the surface and the heat released from there action. As Fig. 5 shows, the heating up time is very short at higher temperature range for ipil-ipil wood indicates the faster decomposition of the solid to liquid vapor and also the organic molecules to gas as discussed earlier which led to the higher gas yield at a cost of liquid yield as discussed earlier. As Figs. 6 and 7 show, to reach the final temperature at the center takes longer time for krisnachura and koroi woods. In the pyrolysis reaction, if the particle heating rate is slow, the condition more likely facilitates the recombination of the molecules to form solids rather than the formation of the liquid vapor. This is the reason of higher char yield for krisnachura and koroi woods as discussed earlier.

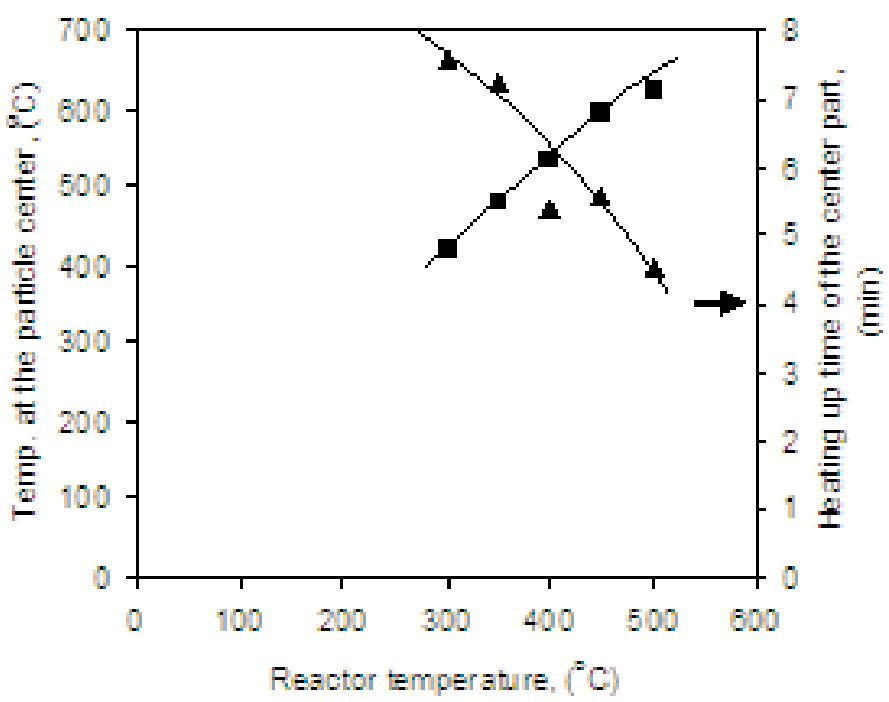

Fig. 7. Resulted final temperature and the duration of volatile release as a function of reactor temperature for koroi wood.

\section{Conclusion}

The experiments were carried out at different temperatures ranging from 300 to $500{ }^{\circ} \mathrm{C}$ reactor temperature. Relatively bigger particle of the wood (3-4 cm -lengthand 2-3 cm diameter), real size for pyrolysis, was used. Special emphasis was given to investigate the effects of heating rate and heating up time of the central mass of the particles on the product distribution. In each experiment, the temperature at the central part was low at the initial stage of pyrolysis while the surface temperature reached to the reactor set temperature immediately. The center temperature gradually increased and reached to the final temperature in 3 to 8 minutes, depending on the wood type and the reactor set temperature. The heating rate and heating up time of the central mass greatly affected the product distribution. For ipil-ipil wood the heating rate of the central mass was much faster than krisnachura and koroi woods, and thus the heating up time was lower. This was resulted in the higher yield (65\%) of bio-oil even at lower reactor temperature $\left(300{ }^{\circ} \mathrm{C}\right.$, particle temperature $450{ }^{\circ} \mathrm{C}$ ) from ipil-ipil wood. In the case of krisnachura and koroi woods, the bio-oil yields were lower under the same condition. This was because the heating rates of the central parts were much slower. Further research especially for different biomasses need to carry out to merge with the biomass conversion technologies. 


\section{Acknowledgement}

The authors thank the Department of Applied Chemistry and Chemical Engineering for kind cooperation and financial support to proceed with this challenging research activities. The authors also thank to National Science and Information \& Communication Technology (NSICT) for financial help to complete this research activities.

\section{References}

Asadullah M, Miyazawa T, Ito SI, Kunimori K, Yamada M and Tomishige K (2004), Gasification of different biomasses in a dual-bed gasifier system combined with novel catalysts with high energy efficiency, Appl Catal A- Gen. 267(1): 95-102.

Asadullah M, (2014), Barriers of commercial power generation using biomass gasification gas: a review, Renew Sust Energ Rev. 29: 201-215.

Asif M and Muneer T (2007), Energy supply, its demand and security issues for developed and emerging economies, Renew Sust Energ Rev. 11(7): 1388-1413.

Awal MR (2010), Environmentally Conscious Petroleum Engineering, Environ Consc Fossil Energ Produc. 1-86

Banik SK, Rouf MA, Khanam M, Islam MS, Rabeya T, Afrose F and Saha D (2015), Production of bio-diesel from Pithraj (Aphanamixis polystachya) seed oil, Bangladesh J Sci Ind Res. 50(2): 135-142.

Bentley RW (2002), Global oil \& gas depletion: an overview, Energ policy. 30(3): 189-205.

Demirbas A (2004), Combustion characteristics of different biomass fuels, Prog Energ Combust. 30(2): 219-230.

Demirbas A (2004), Effects of temperature and particle size on bio-char yield from pyrolysis of agricultural residues, J Analyt Appl Pyrol. 72(2): 243-248.

Dincer I (2000), Renewable energy and sustainable development: a crucial review, Renew Sust Energ Rev. 4(2): 157-175.

Dodic SN, Popov SD, Dodic JM, Rankovic JA, Zavargo ZZ and GolušinMT (2010), An overview of biomass energy utilization in Vojvodina, Renew SustEnerg Rev. 14(1): 550-553.
Ganesh A and Banerjee R (2001), Biomass pyrolysis for power generation-a potential technology, Renew Energ. 22(1): 9-14.

Grubler A (2012), Energy transitions research: Insights and cautionary tales, Energ Policy. 50: 8-16.

Ghose MK (2013), Promotion of clean coal technologies for meeting energy demands in a sustainable manner, JMech Eng. 42(1): 15-20.

Hasan ATMK, Mohiuddin M, Ahmed MB, Poly IJ, Asadullah M and Rahman MS (2011), Production and characterization of bio-oil from bio-mass by circulating fluidized bed pyrolysis reactor, Bangladesh $J$ Sci Ind Res. 46(3):313-322.

Hasan ATMK (2010), Prospect of renewable energy in Bangladesh-bio-oil from biomass, Mohiuddin M, Ahmed MB, Poly IJ, Asadullah M, and Rahman MS, pp 7-11, University of Development Alternative (UODA), Dhaka, 2010.

Imran HM, Khan AH, Islam MS, Niher RS, Sujan A and Chowdhury AS (2012), Utilization of Karanja (Pongamia pinnata) as a Major Raw Material for the Production of Biodiesel, Dhaka Univ J Sci. 60(2): 203207.

Kanakraj S, Dixit S and Rehman A (2015), Biofuel derived from enzymatic degummed linum usitatissimum seed oil: as a potential resource for diesel engine, Bangladesh J Sci Ind Res. 49(1): 13-24.

Kaygusuz K (2002), Sustainable development of hydropower and biomass energy in Turkey, Energ Convers Manage. 43(8): 1099-1120.

Kinoshita C M, Turn SQ, Overend RP and Bain RL (1997), Power generation potential of biomass gasification systems, J Energ Eng. 123(3): 88-99.

Kibria SS, Nahar TN and Mia MM (1994), Tree leaves as alternative feed resource for Black Bengal goats under stall-fed conditions, Small Ruminant Res. 13(3): 217222 .

McKendry P (2002), Energy production from biomass (part 2): conversion technologies. Bioresour Technol. 83(1): 47-54. 
Moriarty P and Honnery D (2009), What energy levels can the Earth sustain? Energ Policy. 37(7): 2469-2474.

McNelis B, van Roekel G and Preiser K (2002), Renewable energy technology for developing countries, the future for renewable energy: prospects and directions. EUREC Agency, London. 20: 40-60.

McGowan F (1991), Controlling the greenhouse effect: The role of renewables, Energ Policy. 19(2): 110-118.

Mwang'ingo PL, Kibodya G and Mng'ong'oAR (2010), Oil yield and quality variation between sexes in Osyris lanceolata (African sandalwood) and its value as a fodder plant in Tanzania, South Forests. 72(2): 69-74.

Nessa A, Pimpi SK and Akand K (2015), Status of Biogas Production in Tangail District, Bangladesh, $J$ Environ Sci \& Natural Resources. 7(1): 81-85.

Rana SMS, Haque MA, Poddar, Sujan SMA, Hossain M and Jamal MS (2015), Biodiesel production from nonedible Mahogany seed oil by dual step process and study of its oxidation stability, Bangladesh J Sci Ind Res. 50(2): 77-86.

Rao AB and Rubin ES (2002), A technical, economic, and environmental assessment of amine-based $\mathrm{CO}_{2}$ capture technology for power plant greenhouse gas control, Environ Sci Technol. 36(20): 4467-4475.

Sakaki K and Yamada K (1997), $\mathrm{CO}_{2}$ mitigation by new energy systems, Energ Convers Manage. 38: S655S660.

Saleh AA, Hamdan S, Annaluru N, Watanabe S, Rahman MR, Kodaki T and Makino K (2010), Conversion of Waste Agriculture Biomass to Bioethanol by Recombinant Saccharomyces cerevisiae, J Sci Res. 2(2): 351-361.
Sharma SK, Mishra IM, Sharma MP and Saini JS (1988), Effect of particle size on biogas generation from biomass residues, Biomass. 17(4): 251-263.

Suarez JA, Luengo CA, Felfli FF, Bezzon G and BeatÓn PA (2000), Thermochemical properties of Cuban biomass, Energ Source. 22(10): 851-857.

Song C, Gaffney AF and Fujimoto (Eds.) K (2002), $\mathrm{CO}_{2}$ conversion and utilization: An Overview, ACS Symposium Series 809, American Chemical Society, Washington, DC. pp 2-30.

Van den Broek R, van den Burg T, van Wijk A and Turkenburg W (2000), Electricity generation from eucalyptus and bagasse by sugar mills in Nicaragua: A comparison with fuel oil electricity generation on the basis of costs, macro-economic impacts and environmental emissions, Biomass Bioenerg. 19(5): 311-335.

Vargas AM, Cazetta AL, Garcia CA, Moraes JC, Nogami EM, Lenzi E and Almeida VC (2011), Preparation and characterization of activated carbon from a new raw lignocellulosic material: Flamboyant (Delonixregia) pods, J Environ Manage. 92(1): 178-184.

Yousuf A, Iqbal SA, Sarker NC, Hasan MN and Sarker MSH (2014), Optimization and fabrication of a portable biogas reactor, J. Chem. Eng. 27(2): 36-40.

Received: 10 June 2014; Revised: 06 September 2014; Accepted: 19 October 2015. 